\title{
The translation technique and the translation of verbal forms in Psalm 84 of the Masoretic Text as employed by the Peshitta
}

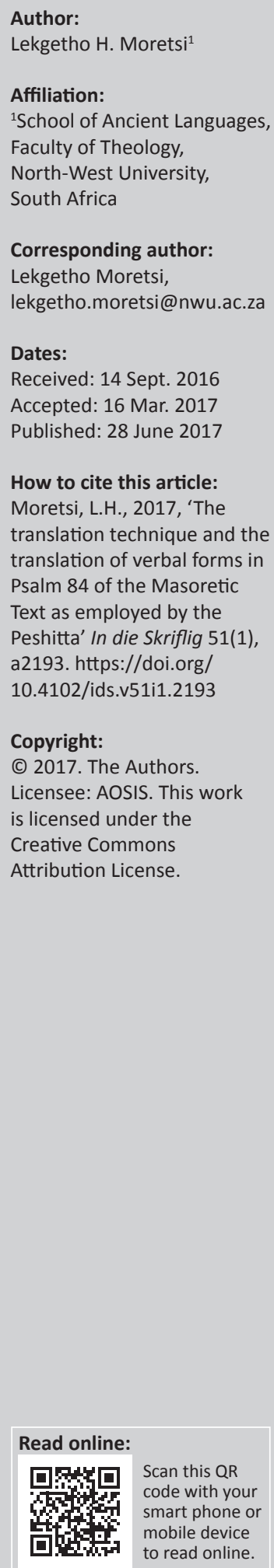

\begin{abstract}
This article was inspired by the study of translation techniques and verbal systems in Book 3 of The Book of Psalms in the Peshitta. In addition, the article focuses on Psalm 84 due to the broad scope of such a study. Psalm 84 opens the second group of Korah Psalms (Ps 84-85, 87-88) and shows a number of similarities to the first group of Korah Psalms (Ps 42-49). The differences between Psalm 84 and Psalms $42-43$ are as striking as their similarities because of the fact that they are identified as Korah Psalms (cf. Goldingay 2007:587; Wallace 2009:140). This article argues that the translation technique, employed by the Peshitta, resulted in important differences at some points. As expected, the Peshitta uses the conjunctive verb at times in places where it is absent from the Masoretic Text. In addition, the Peshitta does not have the waw consecutive construction found in the Masoretic Text and uses the conjunctive waw in most instances. This article further argues that different verbal forms are used in a sensible way in both the Masoretic Text and the Peshitta, and that the content of verses also differs. In some places, certain parts of the verses, as they appear in the Masoretic Text, are omitted by the Peshitta. Some of these omissions may be ascribed to different Hebrew Vorlagen while others may be ascribed to the translation technique followed.
\end{abstract}

\section{Introduction}

It is a well-known fact that the Psalter in both the Masoretic Text $(\mathrm{MT})^{1}$ and the Peshitta $(\mathrm{P})$ did not come to $\mathrm{us}^{2}$ in its original version, but in the form of manuscripts (MSS) that came from the hands of the last scribe who, in some way, brought this poetic book to a close (cf. Carbajosa 2008:1). Nearly 900 scrolls of Hebrew Old Testament manuscripts were discovered at Qumran. The Book of Psalms is included in more of these manuscripts than in any other book. This provides clear evidence that the Psalter was of fundamental importance to the people of Qumran (cf. Flint 2007:157). The Psalter is included in manuscripts containing the ancient versions. The Hebrew manuscripts are direct witnesses to the 'original' text while the ancient versions are widely accepted as 'indirect witnesses'. ${ }^{3}$ It is therefore crucial to consider a series of issues that arise before using the ancient versions for the textual criticism of the Old Testament. The fact that the Syriac language was one of the early Semitic languages next to the Hebrew and that the 'original' Hebrew or Aramaic canon was translated into this language, marks its importance in relation to the larger textual history (cf. Hiebert 2005:505; Weitzman 1999:2).

Since investigations of the P started, most of the investigations concentrated on influences from other versions thereof, especially the Septuagint (LXX) and the Targum (T). This is also the case when it comes to research on the P version of the Book of Psalms. The influence of other versions on the Syriac versions conditioned the research performed. The aim of this article is to pay attention to the translation technique employed in the translation of the P-psalms (Peshitta psalm).

With regard to the translation technique, this article pays special attention to the Syriac variants as compared to the MT, especially those variants that does not coincide with the LXX and/or the $\mathrm{T}$ or vice versa. The lectiones that can be attributed to the translation technique and other aspects that may point to a different Hebrew Vorlage are also explored. These are two different options for variants - a different Vorlage or a translation technique.

\footnotetext{
1.When an abbreviation is given in brackets, only the abbreviation will be used further on in the article.

2.'Us' is used in this text to refer to today's readers.

3.Goshen-Gottstein (1963:132) argues that the variants of the Hebrew MSS and the testimonies of the ancient versions should not be
} mixed with the critical apparatus of the Hebrew Bible. 
This investigation is based on the Leiden edition of the P-psalms and follows the divisions of psalms and numbering of verses characteristic of the Biblia Hebraica Stuttgartensia (BHS) (Elliger \& Rudolph 1967). The P psalter differs slightly from these divisions when compared to the MT on the one hand and compared to the LXX on the other hand. Another reason for the choice to follow the numbering of the BHS is that the Leiden edition does not include the Syriac titles of the psalms. The investigation did not pay attention to titles as they are not dependent on the MT.

Psalm 84 marks the beginning of the second Korah collection (Ps 84-89). It is a well-known and loved psalm, but it presents several problems. This article aims to address some of these problems by looking at the verbs as they are employed in both the MT and the P. Not all the verses are used in this attempt. Verses were chosen that could make a significant contribution to this research. The following verses ${ }^{4}$ are used for this purpose: 6-8 and 10-11. Some words or phrases in verses 2, 3, 4 and 5 also received attention. In an attempt to solve the problem of the interpretation of some of the words or verbs used in the $\mathrm{P}$ translation, the discussion is divided into the following sections:

- The translation technique

- An interpretation of problematic terms

- An analysis of the verbal system

- Conclusion

\section{The translation technique}

Before assessing the value of variant readings by comparing the MT with the $\mathrm{P}$, it is perhaps important to pay attention to the translation technique employed. Gordon (2006:255) argues that it is difficult to generalise meaningfully about such a large undertaking as the $\mathrm{P}$ translation of the Old Testament. He further argues that the translators inevitably made mistakes, sometimes found their task too difficult and occasionally took liberties with the text. The $\mathrm{P}$, as witness to the MT, is to be investigated in relation to the MT as a base text in order to determine the similarities and deviations between the two. Studies in the field of ancient translations are generally interested in distinguishing the techniques used to arrive at a translation based on two primary criteria: fidelity and intelligibility. The balance within a given translation is often indicated by describing it as either literal or free (Weitzman 1999:22). Literalism is subdivided into different categories that each receives special attention from translators. Ultimately, a translation may be literal in one of these categories and free in another. Weitzman (1999:22-26) classifies these categories as first, the segmentation of a text; second, quantitative correspondence; third, imitation of the form of the Hebrew present in the source text; and fourth, consistency of equivalences. Adair (1997:181, 187) suggests what he describes as 'a much more nuanced description of the translation technique' aimed at producing a fully quantitative description. He (Adair 1997:187) proposes that the four above-mentioned categories, referred to by
Weitzman, should be quantitatively analysed to determine upon which descriptive evaluation these categories are based. In my view, this statistical approach is instructive and receives acceptance in textual studies.

The investigation made use of a comparative text-critical method to determine the translation technique used in the P version of Psalm 84. The P-psalm is compared to the MT by employing a critical and literary analysis as a tool to arrive at an interpretive description. The internal evidence, found in the two texts, has already shown that the P version is based on a Hebrew text (cf. Weitzman 1999:1). For this reason the investigation viewed the MT as a hypothetical Vorlage of the translation of the P-psalm. Even if this is the case, one cannot ignore the fact that some scholars frequently characterise the $\mathrm{P}$ as directly influenced by the LXX and that the influence is clearly visible in the psalms (cf. Barnes 1901:187; Lund 1995:85; Weitzman 1999:68ff.). As a result, the article also compared the P with the LXX, taking into consideration other versions that may shed light where the Hebrew and the Syriac cannot lead to a convincing conclusion.

The central focus was on the Syriac variants that differ when compared with the MT due to the requirements of the language and the technique that the translator of the version employed (that is, the difference is not as a result of influence, but due to language structure). The Syriac agreements with the MT, which do not coincide with either the LXX or T, were also investigated. Aspects that can be attributed to the translation technique employed also received attention. The interpretations of problematic terms were explored in an attempt to offer some solutions. To achieve this goal, the investigation looked briefly at syntactic, morphological and semantic relations.

\section{Syntactic function}

\section{Word order and specific phrases}

Syriac is a flexible and a free language, and one may expect that the word order will follow the MT closely (cf. Lambdin 1973:39; Van der Merwe, Naudé \& Kroeze 1996:273; Nöldeke 1966:248; Muraoka 1987:40-69). However, this is not the case. In some instances, the Syriac version deviates from the MT. The P-psalm 84 is a particularly striking example of such a deviation, as its word order is not fixed.

When considering specific phrases it is important to note, for instance, how the different versions use different terms in verse 2. The following abbreviations are used onwards when examples are provided: Masoretic Text = MT; Peshitta = P; Septuagint $=$ LXX; and Targum $=\mathrm{T}$. The following examples illustrate the use of different terms in the following verses:

Verse 2

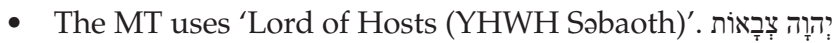

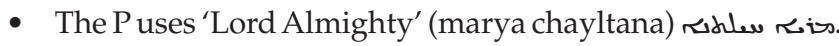

- The LXX uses 'Lord Almighty' Kupıє $\tau \omega v \delta v v \alpha \mu \varepsilon \omega v$. 
The $\mathrm{P}$ translates Hebrew in its own way with the use of sulew - an adjective meaning strong or powerful. This is the common translation in the $\mathrm{P}$ for this Hebrew phrase. The $\mathrm{P}$ agrees with the LXX translation in this regard. Psalm 84 refers to God as 'Lord of Hosts' four times. The term Lord of Hosts (Briggs 1976:226; Tate 1990:353) is associated with the ark that is the symbol of God's willingness to sojourn among his people.

Verse 3

Word order:

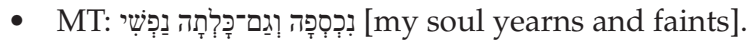

- P: sakayt nafs̆̀y wa'etrgargat dय i idro, soul yearns and faints].

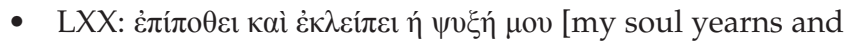
faints] (Taylor 2009; Bagster 1870).

The P moves the subject, to after the first verb. This change in word order makes the sentence easier to read and can be viewed as an example of simplification. The LXX retains the word order of the MT. However, the P does not follow the word order of the MT in this instance.

Verse 4

Word order:

In the first line of this verse, the MT places the preposition ה

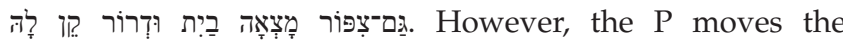
preposition to the first half of the line (ap tsepra ashkxat lah byta weshupanayana qena):

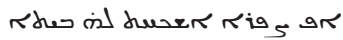

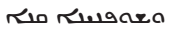

This is again another example of simplification. The LXX places the preposition in both halves of the line

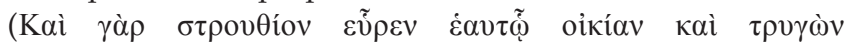

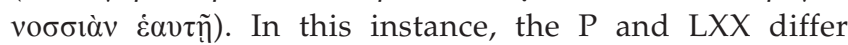
from each other and serve as an argument against the influence of the LXX on the P. The same mechanism appears in verse 10 .

\section{Interpretation problems with regard to Psalm 84}

Verse 5:

- MT: The MT has a construct chain in the first line of the verse: 'dwellers of your house' or 'they who dwell in your

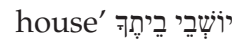

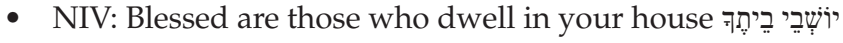

- Vulgate: beati qui habitant in domo tua [Blessed are they who dwell in your house]. The Vulgate has a relative sentence with a preposition 'in your house'.

- T: טוביהון דצדיקין דיתבין בבית מקדשך [Blessed are the righteous who dwell in your holy house]. It has a relative construction with a preposition, but retains the participle of the Hebrew.

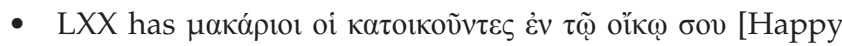
are those who dwell in your house]. It retains the participle of the Hebrew, but uses a preposition.

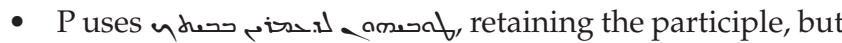
also using a preposition in a relative phrase. Three of the versions provided retained the participle, but all of them used a preposition before 'house'. The $\mathrm{P}$ and $\mathrm{T}$ have a relative phrase while the LXX uses a participial phrase. This constitutes another case of simplification in the P.

Verse 6:

- At the end of the verse, the MT makes use of the following

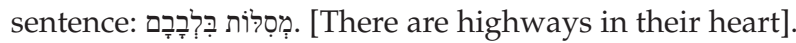
The P changes the suffix 3 masculine plural to 3 masculine singular. The MT uses a plural suffix together with a noun in the singular (the person) in the first half of the line. In this instance, the $\mathrm{P}$ harmonises the second part of the verse with the first part by adding a suffix to 'highways' (Your highways are in his heart).

- P: متحسلeي حلحس. (wa shbylyg blbh).

Both readings are very difficult to understand and making this sentence difficult to interpret. מִọ (Mesiloth) is viewed by most commentators as the plural form of מִ מִ מדi (Mesilla) [highway]. It can have various interpretations:

- (your) ways are in their heart(s), or

- high praises are in their heart. Thus taking מְִִ̣ the plural

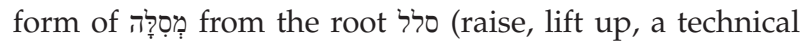
term for (re)building road).

The LXX differs so much from the Hebrew in this verse that a

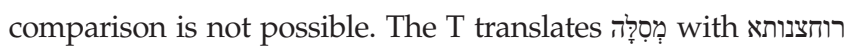
[trust]. It changes the metaphor to an abstract idea. Merrill

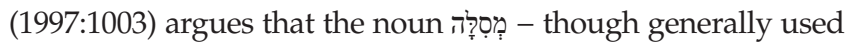
as a designation for a literal highway - occurs at least twice as a metaphor for spiritual pilgrimage. In 84:5(6) the psalmist speaks of the righteous who have set their hearts on the things of God. The upright are said to pursue a highway that leads away from evil, the one that preserves them as they hold fast to its way (Pr 16:17). It is important to maintain the reading as it is found in the MT. The translator of the P probably had the reading of the MT before him, but tried to simplify and harmonise it.

Verse 7

The most problematic aspect with verse 7 is the interpretation

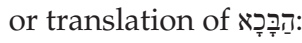

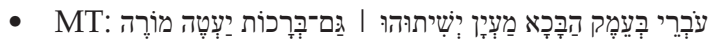

- NIV: As they pass through the Valley of Baca, they make it a place of springs; the autumn rains also cover it with pools.

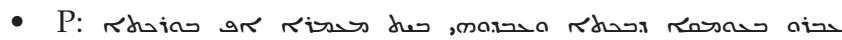
reocs srealydu [They will go through the valley of weeping and they will make it a dwelling place. Also the law-giver will cover it with blessings.] 


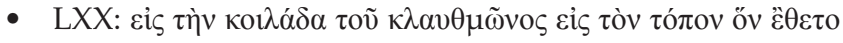

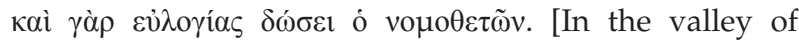
weeping, to the place which he has appointed, for there the law-giver will grant blessings.]

- MT: הַבָכָכָ [Baca]

- P: 'of weeping' (זح

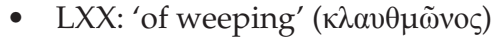

The $\mathrm{P}$ differs from the MT. The interpretation of the $\mathrm{P}$ is based on a different understanding of an unvocalised Hebrew text, perhaps pointing to the influence of the LXX. The Hebrew word can be regarded as the name of an unknown valley.

It seems that the Vulgate, Aquila, Jerome and the Syriac accept that the word is בֶכָה [weeping], as used in Ezra 10:1. The LXX uses 'in a hollow/valley of a place of weeping'.

Although the Old Testament does not mention this unknown valley, it is fair in this regard to translate the Hebrew text as 'the valley of Baca' - in other words as a proper noun (cf. Hossfeld \& Zenger 2005:355; Kraus 1993:169). The other problem in this verse is the word רִרְכוֹת [blessings]. Some

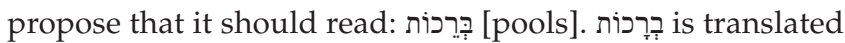
by the LXX and Jerome as 'blessings' while both the New International Version (NIV) and New Revised Standard Version (NRSV) translate it as 'pools'. Both the NIV and NRSV viewed the word in a plural form: בָּרָָּ [pool] Hebrew for the Greek translation $\kappa \alpha \lambda \nu \beta \eta \theta \rho \alpha$. However, this is not what one finds in the MT. Robinson (1974:379), in his attempt to interpret this verse, argues that רִרְָ should be translated as 'tender shoots'. According to Robinson, the word should be viewed as the feminine plural of the root 7 ? [tender, frail, weak, shoot], preceded by the preposition ?ִ ? This viewpoint is influenced by the fact that the same word is used in Ezekiel 17:22. Here, 'tender shoots' produces a better reading and provides a better parallel than either 'blessings' or 'pools'.

What is of significance here is that one must remember that the P, LXX and T were all translated from an unvocalised text. This means that the consonants can be interpreted in different ways. In this instance, the different versions all had the same Hebrew text as the source, but translators interpreted the consonants differently. In some instances, the difference between the MT and the $\mathrm{P}$ can be ascribed to different interpretations of the same unvocalised text.

Verse 11

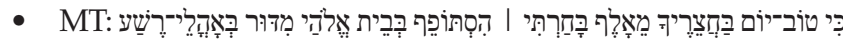
[For better is a day in your courts than a thousand, I have chosen to stand at the threshold in the house of my God rather than dwell in tents of wickedness.]

- NIV (10): Better is one day in your courts than a thousand elsewhere; I would rather be a doorkeeper in the house of my God than dwell in the tents of the wicked.

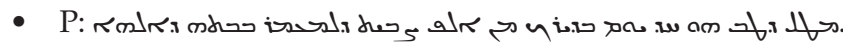
[For better is one day in your dwelling than a thousand, I desire to dwell in the house of God. It is better than to dwell in the tent of the wicked.]

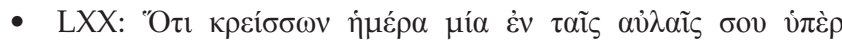

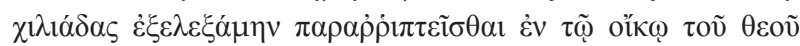

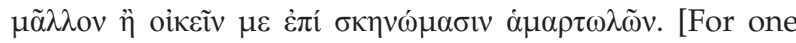
day in your courts is more profitable (or better) than a thousand. I choose rather to be at the threshold in the house of God, than dwell (or sojourn) in the tents of sinners (wicked people).]

Even though the meaning of this verse is clear, the interpretation of been published in an attempt to solve this problem. Traditionally, it is accepted as a verb attached to the next line, as used in the NRSV. It is also possible to view it as a verb attached to the line where it stands as used in the BHS (cf. Robinson 1974:380). Booij (1986:117-120) concentrated on this verse, as a tradition of conjecture is associated with this

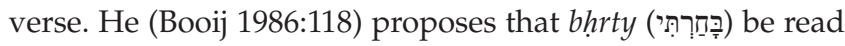
as bhṣrty (bahășêrōtāy) for he believes the second consonant must have fallen away (hạșēr ) and that the sentence should be translated as 'For better is one day in your court than a thousand in my courts'. His proposal of changing the MT is based on literary rather than on linguistic grounds. The greatest desire of the psalmist is to return to the house of God.

In another attempt, Grollenberg (1959:312) proposes that one should read here the noun חרוּ with the sense of liberty and/ or freedom. He deduces this from זרר [free man], [noble] and with a local connotation, his domain or estate.

Another difficulty is the rarity of the two verbs in the

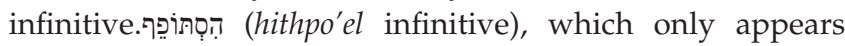
here. The psalmist is reduced to a beggar and hence standing on the threshold. דור, although a Qal, occurs nowhere else in the Hebrew Bible. It means 'to dwell'. When one considers the way in which this word is translated in these versions, there is no support found in the various versions for the proposal of the BHS (my room/dwelling) and all the other proposals to change the text. In this instance, the $\mathrm{P}$ and the other versions confirm the MT, but with the verb linked to the second part of the verse. This is an example of a different division of sentences in the $P$.

To summarise: As seen in the discussion of the above verses, the $P$ has variants absent in Hebrew and does not always keep to the word order of the MT, but can be viewed as free and flexible. As seen in verse 6 , the P employs the use of different suffixes from what is found in the Hebrew source text. When confronted with difficult Hebrew word(s), for example verbs not found in Syriac, the P sometimes employs the use of any word form with a meaning close to Hebrew. At times, the P follows Greek, for example in verse 6 regarding הָבָכָכָה . Moreover, the $\mathrm{P}$ uses a verbal form that completely differs in tense from what is found in Hebrew, for example one would find an imperfect verb in Hebrew and the P translates it with a perfect verb or vice versa (please see 11.3 in 1). 
Both Hebrew and the Syriac language are from the NorthWest Semitic language group. As a cluster, they share a basic verbal system based on the existence of personal forms: the perfect and imperfect, and impersonal participles and infinitives (cf. Carbajosa 2008:46). This sharing of a verbal system creates an expectation that the Hebrew perfect will be translated with the Syriac perfect, the Hebrew imperfect with the Syriac imperfect and that the Hebrew participle and infinitive will also be translated with the Syriac participle and infinitive. However, is this true and is the expectation fully met at all times? Does the P-psalm correspond with the Hebrew verbal system? To answer these above-mentioned questions, the research focused on the analysis of verbal forms in Hebrew as used in the MT and how the Syriac language translates into the P.

\section{An analysis of the verbal system}

The verbal system of Semitic languages is very complex, which makes the tenses used very complicated. This complication resulted from the development of various tense forms and causes confusion regarding meaning and the relationship among these tenses. The P mostly translates perfect with perfect and imperfect with imperfect, but there are instances where the $\mathrm{P}$ translates Hebrew perfect with the imperfect. In many instances, the P uses the verbal form that corresponds with Hebrew. However, the Table 1 concentrates on examples where differences are indicated.
In Psalm 84, Hebrew has 23 verbal forms. Table 1 list these forms with the Syriac equivalents as employed in the P in the second column.

In verse 3, the MT has two verbs in the perfect followed by a verb in the imperfect (3.3) whereas the P keeps the verbs consistently in the perfect tense. In this case, the $\mathrm{P}$ is probably harmonising verse 3.3 with the first two verbal forms.

Verse 4:

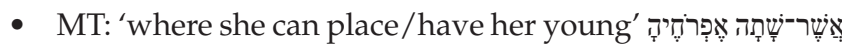

- P: 'her chicks grew up on the side of your altar'

The MT offers a strange use of the verb שית. The P simplifies this by changing the subject and uses a different verb - the perfect is used (like the MT), but simplification criteria are also used to change the subject.

Verse 7

In verse 7.1 , the MT uses a participle to continue from the previous verse instead of a relative clause. The P starts a new sentence with the perfect. In verse 7.2, the MT uses the imperfect while the $P$ translates it as a perfect to maintain the same tense as in verse 7.1.

Verse 7.3 יעטה

Here it seems as if the translators did not understand Hebrew and tried to make sense of it.

TABLE 1: Hebrew and Syriac verbal forms compared.

\begin{tabular}{|c|c|c|c|c|}
\hline Verse & Hebrew form & Parsing & Syriac form & Parsing \\
\hline $3(3.1)$ & נִכְסָפָהּה & Niph perf $3 f s$ & Skyt theo & Pael perf 3fs \\
\hline (3.2) & 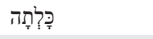 & Qal perf $3 \mathrm{fs}$ & W'tr grgt dy i idro & Hitpalpal perf $3 \mathrm{fs}$ rg \\
\hline (3.3) & 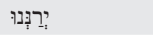 & Piel Impf 3mpl & Šbg عרuת & Pael perf $3 \mathrm{~m}$ pl \\
\hline $4(4.1)$ & 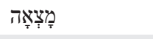 & Qal perf 3fs & 'škxgt Rברטג & Af perf $3 \mathrm{fs}$ \\
\hline$(4.2)$ & שָָׁתה & Qal perf $3 \mathrm{fs}$ & Rbyw i i & Pael perf $3 \mathrm{~m} \mathrm{pl}$ \\
\hline $5(5.1)$ & ירוֹשְברי & Qal part mpl const. & لגרבויم Ld'mryn & Pael part not a cs, but relative clause \\
\hline$(5.2)$ & 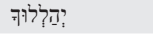 & Piel Impf $3 \mathrm{mpl}$ & Root is šbg שרחטרמט & Pael Impf \\
\hline $7(7.1)$ & עלְברִי & Qal part mpl in const. & רבica & Pael perf $3 \mathrm{mpl}$ \\
\hline$(7.2)$ & 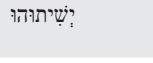 & $\begin{array}{l}\text { Qal Impf } 3 \mathrm{mpl}+\text { suff pointing to } \\
\text { the past }\end{array}$ & ocdwy, a רברום + Peal pf 3 mpl cf. 3.3 & Peal perf instead of an Impf (cf. 3.3) \\
\hline$(7.3)$ & 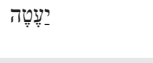 & Qal Impf 3ms & $\begin{array}{l}S^{\prime} m \text { mo two verbs, did not understand Hebrew. } \\
\text { Syriac is quite different from Hebrew. }\end{array}$ & (cf. next page, explanation on 7.3) \\
\hline $8(8.1)$ & יִילְכוּ & Qal Impf 3mpl & N'zlwn alis & Peal Impf \\
\hline (8.2) & יִיָהָה & Niph Impf 3ms & Wntxz' rivdic & Etpeel Impf \\
\hline $9(9.1)$ & שִׁמְעָה & Qal Impt $2 \mathrm{~ms}$ & šmh عدى & Peal Impt \\
\hline $10(10.1)$ & רִאה & Qal Impt $2 \mathrm{~ms}$ & wḥzy, wo & Peal Impt \\
\hline$(10.2)$ & ון והַבֵּט & Hiph Impt $2 \mathrm{~ms}$ & wtswt dia ${ }^{\circ}$ & Peal Impt \\
\hline $11(11.1)$ & 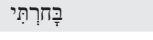 & Qal perf 1c.s & tsbyt dens & Peal perf \\
\hline$(11.2)$ & בִּדוּר & Qal Inf Const מדר & ixdis & $\begin{array}{l}\text { Peal Inf. Constr. is (to dwell) - use Inf, common verb, } \\
\text { for uncommon Hebrew, but meaning fits }\end{array}$ \\
\hline (11.3) & 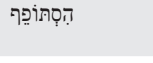 & חיפס Hithpo'el Inf cstr & Lmcmr ('cmr) & $\begin{array}{l}\text { Peal Inf Const - use Inf, common verb, for uncommon } \\
\text { Hebrew, but meaning fits }\end{array}$ \\
\hline \multirow[t]{3}{*}{12} & ? & Qal Impf 3ms & $\mathrm{NtI}$ Jds & Peal Impf \\
\hline & 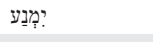 & Qal Impf 3ms & حله Nkl' & Peal Impf irregular \\
\hline & לַהְלְכִים & Qal Part mpl & Dmhlkyn xתמחلحم cf. 5.1 & Peal part, relative clause \\
\hline 13 & 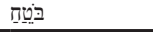 & Qal Part ms & Dmsbr xastix & Peal part, relative clause \\
\hline
\end{tabular}

Source: Clines 1995, 2001; Davidson 1970; Elliger \& Rudolph 1967 (Hebrew Bible/MT/BHS); Holladay 1988; Koehler \& Baumgartner 1958; Smith 1976; Sokolof 2009; VanGemeren 1997 Note: These dictionaries, MT (Hebrew Bible) and P (Syriac Bible) were not only used in the table for the Hebrew and Syriac meaning of words but also in the text for translation. 
In addition, the blessing covers (Ethpael of the verb atp) the one who gives the law (participle swm). 'One who gives the law': מער (Hiphil) means 'to teach'. This highlights a possible influence

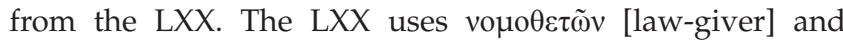

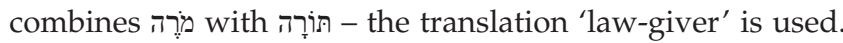
The P followed the LXX in this regard or it was probably revised to reflect the LXX more closely at a later stage. The Hebrew word מערה used in the MT is best translated with 'early rain' (cf. Jl 2:23) and should be translated here as such.

In conclusion, the $\mathrm{P}$ does not correspond directly with the Hebrew verbal system at all times, but deviates from it either narrowly or completely. In the above Table 1, the P translates the Hebrew imperfect with the perfect or vice versa. The $P$ translator remained faithful to the Syriac verbal system or Syriac structure and allowed him- or herself to be directed by the Syriac context rather than following Hebrew to the letter.

Regarding the grouping of verbs as in Table 1 the following characteristics can be found in $P$.

\section{Verse 3}

In the MT, the verbs in 3.1 and 3.2 are used in the perfect tense and the same happens in the P. The MT employs the imperfect for verb in 3.3 while the P uses the perfect tense. It is clear here that the $\mathrm{P}$ is harmonising with the first two preceding verbs.

Verse 4

Both the MT and the P use the same tense.

Verse 5

In this verse, the Hebrew translation makes use of a participle in the construct state whereas the P uses a participle after ' $\mathrm{d}$ ' (ل.حكויה) and uses the preposition instead of the construct chain as is the case in the MT. This can be viewed as an example of simplification.

\section{Verse 7}

In some instances, a phrase with a participle in the MT is translated in the $\mathrm{P}$ as a verb in the perfect, for example in verse 7.1

Verses $8,9,10,11,12$ and 13 all use verbs in the same tense corresponding with one another in the two versions, although there are deviations at certain points in these verses.

\section{Conclusion}

As expected, the $\mathrm{P}$ uses mostly the perfect for the perfect and the imperative for the imperative. However, the $\mathrm{P}$ sometimes uses the perfect for imperfect, especially with the intention of harmonising (please see verbs in 3.3 and 7.2 in the Table 1).

The translation characteristics that emerge when one studies the $\mathrm{P}$ are as follows:
- When faced with difficulties, the translator opted to simplify the text by employing the perfect (cf. verses 3 and 7).

- Participles in construct chains in the MT are translated by participles in a non-construct state, but after relative ' $d$ ', especially in verses 5, 12 and 13 .

- In some instances, the translator harmonised the text, for example by translating a perfect for a perfect or imperfect for imperfect.

- In most cases, it seems that deviations cannot be ascribed to a different Vorlage, but to the fact that the $\mathrm{P}$ translator misunderstood Hebrew. Verse 7 provides a perfect example of such a misunderstanding. As a result, the translator may have introduced a variant text that occurs nowhere else among other versions or witnesses.

- With the above-mentioned characteristics in mind, one can argue that the P used a source text similar to the MT. Most of the differences can be ascribed to either the translation technique employed or to a misunderstanding of Hebrew.

The $\mathrm{P}$ is a testimony of quite a number of examples of simplification and harmonisation as far as verbs are concerned. The P uses, for example, the perfect where the MT uses the imperfect form - pointing to the past and participles not in a construct state.

\section{References}

Adair, J.R., 1997, “'Literal” and "Free" translations: A proposal for a more descriptive terminology', Journal of Northwest languages 23(1), 181-209.

Bagster, S., 1870, The analytical Greek lexicon, Samuel Bagster \& Sons, London.

Barnes, W.E., 1901, 'On the influence of the Septuagint on the Peshitta', Journal of Theological Studies 2, 186-197. https://doi.org/10.1093/jts/os-II.6.186

Booij, T., 1986, 'Royal Words in Psalm LXXXIV 11', Vetus Testamentum 36, 117-120. https://doi.org/10.1163/156853386X00195

Briggs, C.A., 1976, The international critical commentary on the Book of Psalms, T\&T Clark, Edinburgh.

Carbajosa, I., 2008, The character of the Syriac version of Psalms: A study of Psalms 90-150 in the Peshitta, Brill, Leiden/Boston.

Clines, D.J.A., 1995, The dictionary of classical Hebrew, $\beth-ı$, vol. 3, Sheffield Academic Press, Sheffield.

Clines, D.J.A., 2001, The dictionary of classical Hebrew, $y-1$, vol. 5, Sheffield Academic Press, Sheffield.

Davidson, B., 1970, The analytical Hebrew and Chaldee lexicon, Zondervan Publishing House, Grand Rapids.

Elliger, K. \& Rudolph, W., 1967, Biblia Hebraica Stuttgartensia (BHS), Deutsche Bibelstiftung, Stuttgart.

Flint, P.W., 2007, The Book of Psalms: Composition and reception, Brill, Leiden/Boston. Goldingay, J., 2007, Psalms: Psalms 42-89, vol. 2, Baker Academic, Grand Rapids.

Gordon, R.P., 2006, Hebrew Bible and ancient versions: Selected essays of Robert P. Gordon, Ashgate Publishing Limited, Aldershot, England.

Goshen-Gottstein, M.H., 1963, 'Theory and practice of textual criticism: The textcritical use of the Septuagint', Textus 3, 130-158.

Grollenberg, L., 1959, 'Post-biblical in Ps. LXXXIV 11', VetusTestamentum 9(1-4), 311-312. https://doi.org/10.1163/156853359x00339

Hiebert, R.J.V., 2005, 'The place of the Syriac version in the textual history of the Psalter', in P.W. Flint (ed.), The Book of Psalms: Composition and reception, pp. 505-536, Brill, Leiden.

Holladay, W.L., 1988, A concise Hebrew and Aramaic lexicon of the Old Testament, Brill, Leiden.

Hossfeld, F.L. \& Zenger, E., 2005, Psalms 2: A commentary on Psalms 51-100, Fortress Press, Minneapolis.

Koehler, L. \& Baumgartner, W., 1958, Lexicon in Veteris Testamenti Libros, Brill, Leiden.

Kraus, H.J., 1993, Psalms 60-150: A continental commentary, Fortress Press, Minneapolis. 
Lambdin, T.O., 1973, Introduction to biblical Hebrew, Sheffield Academy Press, Sheffield

Lund, J.A., 1995, 'Grecisms in the Peshitta psalms: The Peshitta as a translation, in P.B. Dirksen \& A. van der Kooij (eds.), The Peshitta as a translation, vol. 8, pp. 85-102, Brill, Leiden.

Merrill, E.H., 1997, 'Mesill', in W.A. VanGemeren (ed.), New international dictionary of Old Testament theology \& exegesis, vol. 2, pp. 1003-1004 Zondervan, Grand Rapids.

Muraoka, T., 1987, Classical Syriac for Hebraists, Otto Harrassowitz, Wiesbaden.

Nöldeke, T., 1966, Kurzgefasste Syrische Grammatik, Wissenschaftliche Buchgesellschaft, Darmastadt, Germany.

Robinson, A., 1974, 'Three suggested interpretations in Psalm 84', VetusTestamentum 24(3), 378-381. https://doi.org/10.1163/156853374X00350

Smith, J.P., 1976, A compendious Syriac dictionary: founded upon the Thesaurus Syriacus of R. Payne Smith, Clarendon Press, Claredon.
Sokolof, M., 2009, A Syriac lexicon: Translation from the Latin, correction, expansion, and update of C. Brockelmaan's Lexicon Syriacum, Eisenbrauns, Winona Lake, Indiana.

Tate, M.E., 1990, Word biblical commentary: Psalms 51-100, vol. 20, Word Books, Dallas, Texas.

Taylor, B.A., 2009, Analytical lexicon to the Septuagint, expanded edn., Hendrickson Publishers, Peabody, Massachusetts.

Van der Merwe, C., Naudé, J. \& Kroeze, J., 1996, A biblical reference grammar for students, vol. 1, PU for CHE. Potchefstroom.

VanGemeren, W.A., 1997, New international dictionary of Old Testament theology and exegesis, vol. 2, Zondervan Publishing House, Grand Rapids, Michigan.

Wallace, H.N., 2009, Psalms, Sheffield Phoenix Press, Sheffield.

Weitzman, M.P., 1999, The Syriac version of the Old Testament: An introduction, Cambridge University Press, Cambridge. 